\title{
Ryhmätyöstä kirjoitettua
}

Jos ihmistä koskevassa tutkimuksessa ja toiminnassa halutaan kapea luonnontieteellinen ihmiskäsitys vaihtaa avarammaksi ihmisen erityislaadun huomioonottamiseksi, siihen tuskin riittävät pelkät teoreettiset pohdinnat. Kuten Marx kirjoittaa, '’ihmisen täytyy todistaa käytännössä ajattelunsa totuudellisuus, so. sen todellisuus ja voima, sen tämänpuolisuus"'. Jos esimerkiksi sanotaan, että moniin ongelmiin ja ahdistuksiin, joita nyt hoidetaan 'tautina' lääkkeiden avulla, olisi parempiakin käsittelykeinoja, pitäisi sanojen tueksi olla näyttöjä tuollaisista keinoista.

Yhden sellaisen keinon näin aikoinaan ryhmätyössä. Kuten Liisa Hietalahti hyödyllisessä suomalaisen ryhmätyön historiikissaan (5) kertoo, 70-luvun alussa Tampereen yliopistoon esitettiin sosiaalipsykologian apulaisprofessorin virkaa, erityisalana ryhmätyö. Ryhmätyön koulutusohjelmakin oli yhteen aikaan suunnitteilla laitokseemme. Valitettavasti ryhmätyöhön kiinnostuneita ja sitä tutkimalla pätevöityneitä hakijoita ei apulaisprofessoriksi tarjoutunut, niin että virka sitten täytettiin erityisalaa koskevasta maininnasta paljon piittaamatta.

Ryhmätyö ei kyennyt työntämään juuriaan yliopistotutkimuksen kasvualustaan, vaan jäi suurelta osin kirjavan, itseoppineen harrastelijajoukon epäilyttäväksi kauppatavaraksi. Yhteen aikaan kentän julkaisuja hallitsi jonkun "Matin" ja "'Pekan" ja "'Ritvan" ja "Pirkon', tai keitä heitä oli, kummallisen sisäryhmäjutustelu - etenkin asianomaisten tunneelämää kiivaasti vispanneiden kesäkurssien jälkeen.

Ulkopuoliselle antoi homman tasosta kuvan Pehr Charpantierin omakustanne (3), joka kritiikittömän innostuneesti esitetyn, sieltä täältä jo vanhentuneen oppikirjapsykologian lomassa salakuljetti ryhmätyöhön puhtaasti ideolo- gista propagandaa. Kirjan aiheuttama ärtymys väritti minun suhtautumistani Charpentieriin ja hänen leikkeihinsä television "'Aikapommissa". On harmi, ettei Charpantier kokeneena ja omalla laillaan taitavanakin ryhmätyöntekijänä rakentanut kirjaansa enemmän niiden konkreettisten episodien varaan, joita härien ryhmissään todella on tapahtunut.

Bionin klassinen teos (2) osoittaa, miten yksinkertaisista konkreettisista kokemuksista, neuvottomuutta, haparointia ja virheitäkään piilottamatta, voidaan edetä hyvinkin syvälliseen analyysiin. Ei ryhmätyöntekijän tarvitse olla liukas luikku, jolla on ranskalaisin viivoin rakennettu luettelo vastauksena jokaiseen $\mathrm{ky}$ symykseen.

Toisen esimerkin ottaakseni: Makarenkon "Paljasjalkaiset isännät" ja "Liput torneissa", (joista toivoisi uudet painokset) ovat komeita ja opettavaisia kirjoja, koska lukija saa seurata jokapäiväisiä tapahtumia ja niissä kehiteltyjä opetuksia. Minä en tarvitse kirjalliseen muotoon puettuja kaavoja, joita kuitenkaan en olisi voinut sovelluttaa työhöni, kirjoittaa Makarenko, vaan "teoria oli kehiteltävä silmieni edessä tapahtuvien reaalisten ilmiöiden summasta'.

Abstraktien määritelmien, kaavojen ja neuvojen lateleminen on kuitenkin sen ryhmiin liittyvän kirjallisuuden tunnusomainen vaiva, jota tämän lehden toimitus minulle lähetti arvioitavaksi. Leinosen vaatimaton moniste (8) lienee tarkoitettu käytettäväksi harjoitusten yhteydessä, joten sitä olisi kohtuutonta moittia pelkän lukemisen nojalla. Opintotoiminnan Keskusliiton oppaista (9 ja 10) sitä vastoin ehkä rohkenen sanoa, että ne ovat hiukan lapsellisia. Onko alentuva tätimäinen lepertely paras tapa puhutella opiskelevia nuoria ja aikuisia? "Opiskelun ei tarvitse olla vakavaa työtä, jota ainoastaan tehdään selkä suorana pöydän ää- 
ressä istuen. Opiskeltavia asioita voi kertailla mielessään milloin tahansa. Muistutteluun kannattaa käyttää lyhyitä joutohetkiä - juuri sellainen saattaa olla tehokasta opiskelua, vaikka se ei rasita." - Voihan nenä.

Omituinen, trivialiteeteista ja likaisesta pik$\mathrm{ku}$ oveluudesta koostuva uusi tuttavuus minulle oli "'neuvottelutaito"'. Kansasen kirjanen (7) ei liene huonoimpia aihepiiristä julkaistuja. Alan tieteelliseen peruskirjallisuuteen (esim. Bacharach ja Lawler, Bargaining, 1981) tutustuminen antaisi kuitenkin lisää terää uhkailujen, bluffien ja juonittelujen opettamiseen. Nyt neuvot ovat vähän hampaattomia: 'Käytetään hyväksi aikaa tauotuksella, viivytyksellä jne." Neuvottelutaidon opettajien neuvokkuus näyttää riittävän juuri samaan pisteeseen kuin sen hiirien aivoriihen, joka keksi että kissalle pitää panna kello kaulaan: 'Liittoudutaan neuvottelussa samanmielisten kanssa ja saavutetaan enemmistö".

Kyösti Kallion kirjalta (6) odotin enemmän; tekijä on sentään ollut töissä sosiologian ja sosiaalipsykologian laitoksilla. Kirja on kyllä asiallinen ja sitä voi varmaan käyttää yhteistoiminnan ja ryhmätyön sosiaalipsykologiaa opetettaessa, mutta ohuus ja kritiikittömyys tekstiä vaivaavat. Ovatko puhe-, viestintä-, neuvottelu-, esiintymis- ja ryhmätyökursseille osallistuvat suomalaiset tosiaan niin yksinkertaista väkeä, että esimerkiksi Gahaganin pienryhmäkirja (4) on heille liian älykästä pohdintaa? Ryhmätyö tahtoo kirjoituskoneen näppäimistöllä aina lipsahtaa tyhmätyöksi - oireellistako?

Kallion ja Gahaganin väliin sopisi tarvittaessa kirja, joka on edellistä pohtivampi ja tutkivampi mutta jälkimmäistä helppolukuisempi. Paketista viimeisiksi jättämäni Aarnion ja Vuorisen (1) sekä Valtion koulutuskeskuksen työryhmän (11) kirjat tähän markkinarakoon ehkä jossain määrin osuvat, etenkin jälkimmäinen.

Aarnion ja Vuorisen opas on tehty Kirkon Koulutuskeskuksen aloitteesta, mutta kirkollisuuden voi toisenlaisessa käytössä helposti sulkeistaa; ei se häiritse. Kirjassa miellyttää sen vakava asiallisuus, alun lyhyt kytkentä ihmiskuviin ja historiaan, nojautuminen kursseilla tapahtuneeseen sekä kirjaa hienokseltaan sävyttävä kriittinen keskustelevuus. Samalla kirja antaa lyhyet selkeät neuvot erilaisista tekniikoista ja harjoituksista. Tietysti sen jotkut illustraatiot ovat hiukan lapsellisia ja harhaanjohtavia, mutta kaiken kaikkiaan: tästä kirjasta pidin.

Paras kirja paketissa ehkä kuitenkin oli Valtion koulutuskeskuksen "'Ryhmätyön käyttö koulutuksessa". Ensimmäinen luku ryhmän sosiaalipsykologisista ja pedagogisista perusteista on tieteellisesti asiantuntevaa mutta myös luettavaa tekstiä. Ryhmätyön suunnittelua ja toteuttamista käsittelevässä luvussa tähdennetään niiden edellytysten selvittämistä, joiden vallitessa ryhmien käyttö on perusteltua: suhtautuminen ei ole myyntimiehen kritiikittömyyttä. Ikävä määräilevä sävy lukua kuitenkin heikentää ('on muistettava', "'on tehtävä', "'on mietittävä’'). Pohdinta menisi perille paremmin kuin komentelu. Kolmas luku, ryhmän työtapojen esittely, vaikuttaa monipuoliselta ja asialliselta, joskin luettelomainen esitystapa sitä mielestäni hiukan rasittaa. Ranskalaisin viivoin tai vastaavin koottu luettelo on usein merkki siitä, että asiaa ei ole viitsitty tai osattu jäsentää rakenteellisesti, heitelty vain jotain mieleen tullutta. Vajavaiseksi silloin jää myös asian ymmärtäminen ja oppiminen tällaisesta esityksestä.

Hienon esimerkin siitä, mitä vuorovaikutusta ja yhteistoimintaa tietoisesti kehittämällä voi saada aikaan, näin viime syksynä erään ulkomaisen yliopiston sosiaalipsykologian laitoksen vuosijuhlassa. Ensimmäiseksi yllättyi laitoksen opiskelijoista, opettajista ja vieraista koostuvan yleisön spontaanisuudesta, jota moni hapannaama olisi pitänyt kurittomuutena. Hyvää puhetta kuunneltiin hiirenhiljaa, välillä nauruun herahtaen, mutta jos puhe oli huono, se pian oli vaarassa hukkua yleisön keskinäiseen puheensorinaan.

Ohjelmassa oli myös yleisökilpailuja, kuten arvaus siitä, mikä seinälle liimatuista lapsenkuvista oli laitoksen kunkin opettajan ipana-aikainen valokuva. Muutaman kerran juhlan mittaan yleisön joukossa kiersi lomake, johon kohdalle osuneet merkitsivät senhetkisen juhlatunnelmansa asteikolla tylsästä oikein mukavaan. Nämä ynnättiin pikapikaa ja siirrettiin salin seinälle rakennetun suuren pahvisen lämpömittarin juhlatunnelmalukemaksi.

Ja mikähän oli yliopisto, mikä maa?

Kyseessä oli Moskovan yliopiston sosiaalipsykologian laitoksen kymmenvuotisjuhla, laitoksen, josta kollegani Galina Andreeva on kyennyt luomaan todellisen kollektiivin, poikkeuksellisen ilmeisesti myös omassa yliopistossaan.

\section{Paketin kirjat ja monisteet}

( 1) Aarnio, Pentti ja Vuorinen Riitta, Vuorovaikutus ja yhteistyö. SKSK 1982.

( 2) Bion, W.R. Kokemuksia ryhmistä. Weilin + Göös 1979.

( 3) Charpantier, Pehr, Ryhmätyön perusteet. Ihmissuhdeopisto 1979, neljäs painos 1981 . 
( 4) Gahagan, Judy, Vuorovaikutus, ryhmä ja joukko. Weilin + Göös 1977.

( 5) Hietalahti, Liisa, Ryhmätyön historiikki. Moniste 1976.

( 6) Kallio, Kyösti, Yhteistyö ryhmässä. Weilin + Göös 1979.

( 7) Kansanen, Anneli, Neuvottelu- ja kokoustaito. Weilin + Göös 1982.
( 8) Leinonen, Ritva, Ryhmätyön perusteita. Moniste.

( 9) Opintotoiminnan Keskusliitto, Opinto-opas. 1976.

(10) Opintotoiminnan Keskusliitto, Opintokerhoopas. 1982.

(11) Valtion koulutuskeskus, Ryhmätyön käyttö koulutuksessa. Valtion painatuskeskus 1981. 